\title{
Proactive industrial policy as the main strategy for improving Russia's competitiveness in the context of global economic processes
}

\author{
Zhamilia Aliaskarova ${ }^{1, *}$, Vadim Pashkus ${ }^{1, *}$, and Ivan Blagikh ${ }^{1}$ \\ ${ }^{1}$ St. Petersburg State University, Universitetskaya nab., 7-9, St. Petersburg, Russia
}

\begin{abstract}
An effective industrial policy in the context of globalization is becoming increasingly possible thanks to the use of a proactive strategy based on the principles of the New knowledge economy. It is not so much import substitution and support for extensive production that comes to the fore, but rather the strengthening of quality potential, primarily in the field of IT, innovation and education as the main sphere of human capital creation. Purpose of this article is to identify the strengths and weaknesses of Russian industrial policy and to show that only a proactive industrial policy can achieve the best results in a modern innovative economy. The authors use research methods such as an analysis of the theoretical aspects of an effective industrial policy of the future using soft power tools based on the concept of economic security, as well as an analysis of Russian experience in this area. This analysis is based on data from statistical indicators of industrial policy and assessment of import substitution coefficients. Based on this, the authors conclude that the success of the import substitution policy directly depends on whether it is an immanent part of economic policy or is carried out solely for political reasons.
\end{abstract}

\section{Introduction}

Import substitution is one of the main problems facing the Russian economy in the "era of sanctions" imposed by a number of Western countries (mainly the US, Canada and the EU) since the beginning of 2014. It is aimed at strengthening the economic independence of the Russian Federation from imported products. It should be noted that this problem has become urgent due to the active policy of the international division of labor and the reduction of certain (less competitive) industries (for example, light industry and electronics) and agriculture. Since then, the issues of import substitution have been actively studied by both Russian (Peregorodieva, Gubina, Blagikh) [1-3] and foreign economists (Bauer, Hart) [4, 5]. Senchagov, in particular, understands import substitution as a process of "stopping the import of certain goods into the country in connection with the development of domestic production" [6]. This means that the problem is considered only within the framework of food security. However, the limitations of this approach became apparent not long ago. Before the implementation of the sanctions policy, most modern authors (Gumerov, Tulcheev, Chekmarev) [7-9] considered import substitution mainly

\footnotetext{
*Corresponding author aliaskarova1996@mail.ru
} 
through the prism of the food market. In this regard, the scientific novelty of this research is a broader view of the import substitution process. The main goal is to identify the problems and mistakes of Russian industrial policy, as well as to propose ways to resolve them. In this regard, the authors set a number of research tasks, including both the development of an integrated approach to understanding the policy of import substitution, and the identification of effective mechanisms for its implementation, indicating in which industries the implementation of this policy is most effective.

\section{Methodology: import substitution as a tool of economic policy}

We should start with the fact that import substitution does not always have a positive impact on the economy of the country that conducts it. Thus, W. Bauer, considering the consequences of import substitution for the economies of Latin America, notes both the danger of total protectionist measures and the losses associated with the "advantages of country's specialization" in the international division of labor. Protection usually confines the protected manufacturer to the domestic market and so inhibits the exploitation of economies of scale, especially in small countries and in industries [10]. Protectionist policies and an increase in the share of state ownership reduce the motivation for entrepreneurial risk, which leads to a decrease in efficiency. As a result, deficits and debts are largely responsible for the Latin American crisis of the 1980s. [4].

Moreover, import substitution can lead to a number of negative consequences, including environmental degradation. The example of some developing countries (India, Thailand, China) shows that the intensive development of national industry ,at any cost“ and an attempt to intensively increase competitiveness by reducing costs (as the implementation of one of the basic competitive strategies for M. Porter) can lead to environmental crises, reduced quality of life and even man-made disasters. For example, Lyakin and Rogov, who argue that ,the existing rich experience of import substitution in developing countries in the 1960 s and 1970s generally showed the low effectiveness of this strategy" [11], clearly demonstrate that import substitution itself does not solve economic problems, but only emphasizes the problems associated with protectionism policy.

The above examples show that import substitution is often applied regardless of sanctions, as an expectedly effective tool of industrial policy. However, at certain points (sanctions, wars, etc.), import substitution must be carried out on a non-alternative basis. Thus, the need for an import substitution policy (together with a counter-sanction policy) in modern Russia is a response to the so-called sectoral sanctions [12]. The fact is that the modern economic (sanctions) war involves, among other things, a serious undermining of the enemy's economy competitiveness [13]. Consequently, the sanctions are not so much aimed at reducing the country's military potential as blocking the most promising and (or) competitive sectors of the economy, what could lead to an economic crisis [14]. In the words of former Minister of Economic Development of Russia Ulyukaev "the so-called sectoral sanctions are addressed specifically to those sectors of the Russian economy that occupy impressive positions in world markets and have good development potential. This is the gas industry, oil industry, chemistry, petrochemistry, this is the military-industrial complex, financial and banking industry" [15]. Thus, to conduct an effective economic policy, not only "defensive", but also "offensive" strategies are necessary, which imply the use of appropriate tools. This will make it possible to compensate for the decline in sales and reach a fundamentally new competitive level, which will allow us not so much to respond to sanctions as to squeeze the companies of enemy countries from their positions in the global market [16]. This, in turn, will reduce sanctions pressure and may lead to weakening or even lifting of sanctions in the future. That is, import substitution is the first, 
but not the only tool of economic policy that should be applied in this situation. However, it is necessary to start with creating a development base, for which purpose import substitution is used.

So, for example, in their article Polovinkin and Fomichev distinguish the following objectives of import substitution [17], putting economic security in the first place:

1. Ensuring national and state security of the Russian Federation.

2. Achieving technological independence in critical areas.

3. Promoting trade surplus.

4. Growing national leaders to conquer the global market.

In order to show in which sectors import substitution should be carried out in the first place, we will try to formulate a number of principles that this state policy should comply with.

Firstly, import substitution in the era of the knowledge economy should focus on compensation for imported technologies that are on the list of critical ones. "This is an electronic component base, this is a high-tech machine tool industry, instrumental industry, this is equipment for the oil and gas complex, this is the industry of catalysts for chemistry and petrochemistry. If we secure these positions, then we will save huge volumes of national domestic product" [15].

Secondly, import substitution should be consistent with the implementation of the economic security strategy. That is why import substitution cannot be limited to only a few industries (for example, related to food).

Thirdly, import substitution should lead to the creation of new (advanced) technologies, and not to stimulate the "previous day" technology (the policy of catching up development). Otherwise, import substitution will fix only an economic lag and the chance of technological re-equipment of domestic industry will be lost.

Fourthly, import substitution should be focused on the full production cycle without increasing dependence on imports. The fact is that during import substitution, resource flows and business processes should be carefully planned. Otherwise, the actual growth in the production of domestic goods may entail not a decrease, but an increase in the supply of imported components, raw materials and equipment, which often occurs when import substitution is attempted. For example, domestic products are assembled using "screwdriver" technologies when implementing an import-substitution strategy for electronics. Moreover, from the domestic often only workers and, in fact, screwdrivers are present. All tools more complicated than screwdrivers can be imported. In the best case, innovations relate to engineering, software development, marketing, finance, but these technologies, as a rule, are not connected with the real sector, do not create the basis for technological breakthroughs and cannot provide the production of wealth.

Fifthly, the purpose of the import substitution policy is to create a favorable environment conducive to the growth of national industry. According to Russian President Vladimir Putin, "the products of our suppliers naturally have to meet strict standards both in quality and price. In addition, domestic monopolies should not be allowed. Reasonable import substitution it is our long-term priority regardless of external circumstances" [18].

It should be noted that in a number of industries we have our own developments that allow us to create the necessary products and technologies. Often this allows (even with some imperfection) to avoid both serious problems and possible "blackmail" and potential external threats to economic security from sanctions. For example, the presence of the GLONASS system, with all its shortcomings, avoided potential problems with the threat of disabling the GPS system, which was implemented contrary to public opinion and accusations of inefficiency and uselessness. This example demonstrates the need to use certain tools of both industrial and economic policies to implement potentially breakthrough technologies, including such rather "exotic" technologies as "administrative 
marketing". It is important to remember that "administrative marketing" as a technology for introducing substitutes is not universal, because "forced introduction of innovative products leads to increased corruption and lower quality of the product itself" [19]. Administrative marketing goes well with stimulating key sectors, which can have a positive effect on the economy (which happened in the economies of South Korea and China) and stimulate it to grow [20].

\section{Results: import substitution policy for different product groups}

Now let's look at the real state of affairs in the Russian economy and evaluate the contribution of the economic policy of import substitution to real indicators of selfsufficiency. When studying the phenomenon of import substitution, we analyzed the relationship between a number of indicators: the exchange rate (dollar and euro), on the one hand, as well as self-sufficiency indicators and the import / consumption ratio, on the other hand. At the same time, the hypothesis was put forward as the basic one: without an active economic policy, import substitution clearly depends on the exchange rate, while conducting a horizontal industrial policy, the exchange rate also remains one of the leading parameters, but when conducting a consistent proactive industrial policy, the impact of the exchange rate on import substitution is significantly reduced. This applies only to products for which the share of imports in consumption is high. These trends can be considered on the example of some products and the state of Russian economy in the period from 2007 to 2018. The research was conducted on different groups of products; both with a high share of imports and with a low share, as well as for products for which a variety of sociallyoriented state regulation programs (for example, medicines) are applied. For such products, correlation coefficients (showing the strength of the relationship between the studied parameters) and determination coefficients (showing the strength of the relationship between the various parameters) were calculated. Correlation coefficients will help not to miss the presence of a different type of connection (for example, nonlinear) between the parameters in the absence of a linear relationship (determination coefficient). Consider the results for these products, breaking them into groups.

The first group of products analyzed in this research includes meat and poultry, including co-products. This includes beef, pork, lamb, chicken, etc. This group of products is characterized by an ever-growing tendency toward self-sufficiency and it is a good statistical illustration of achieving high indicators of food safety for a group of products that are significant for the population. The share of imports in consumption, which was $60 \%$ in 2007 and less than $15 \%$ in 2018 , is also very indicative, taking into account the fact that a little less than half of the decline in this indicator in percentage terms falls in 2014 and 2015.

According to the results of the research, the main factor of import substitution in this group of indicators is the exchange rate. The analysis demonstrates that the dependence of the exchange rate and self-reliance, direct (the course increases self-rising), and the import - reverse (the course is growing and imports falling), which is possible with a high level of self-sufficiency. The same situation can be observed for cheese, pork, poultry meat, animal oils.

The cheese market has a unique situation. Here the policy of sanctions and import substitution carried out in 2014-2018 is extremely strong. If we consider the situation in the cheese market from 2007 to 2013, we can see that during this period, self-sufficiency in the product was not achieved and this figure was about $60 \%$, and the share of imports in cheese consumption during this period only grew and amounted to $40-50 \%$. The impact of exchange rates on self-sufficiency of a product with an insufficient level of self-sufficiency 
is very small, since the volume of domestic production was not able to meet the needs of the market, and there was no alternative to imports. However, after the introduction of food sanctions and the beginning of the implementation of the policy of import substitution, the situation changed radically and coincided with the situation for the first group of products.

Consider the situation with regard to products for which self-sufficiency has been fully achieved (including self-sufficiency in production). These include, for example, flour from cereals and legumes. Self-sufficiency on consumption by the population in this case steadily exceeds 3 , and on production fluctuates about 1 . Exports and imports in natural form are insignificant. The share of imports in consumption is minimal. It can be assumed that the impact of exchange rates on the market of these products will be negligible. Let's check this hypothesis.

The results of the analysis show that the coefficient in this product group differs from the coefficients in other product groups. For example, there is an inverse relationship between exchange rates and production self-sufficiency, as well as a direct relationship between the exchange rate and the share of imports in consumption. However, the coefficient of determination for these parameters is significantly lower than 0.5 , which indicates the absence of correlation.

There may be a multidirectional dynamics of the relationship between exchange rates and self-sufficiency. As an example we can serve confectionery - a product that is most suitable for use immediately after production.

The correlation and determination coefficient values for this type of products by the share of imports in consumption are extremely small, which confirms the hypothesis that there is no influence of exchange rates on the share of imports in consumption. On the other hand, the values of the same coefficients on the parameters of self-sufficiency are quite large, which shows a significant impact on this parameter of the growth of exchange rates.

The example of confectionary is not the only one. Even more illustrative "divide" takes place in the production of fertilizer, where it is possible to observe multidirectional trends. The impact of movements in currencies in regards to indicators of self-sustainment is practically non-existent. Moreover one is able to observe a certain impact on the import share of consumption. This, under current parameters of self-sustainment of more than $400 \%$ shows good export potential.

On the other hand, an insignificant impact of movements in currencies must be apparent in case of substantial dependency on import, when the value of the self-sustainment coefficient does not exceed 0,31. As an example let us look into Shoes out of leather. Problems with self-sustainment in the production of the latter are absolutely apparent. In the analysis we were able to distinguish a rather unordinary relationship between the parameters of self-sustainment, the correlation of import/consumption and the movements in currency. Our impression is as follows: predominantly non-price factors are active in the market. This is due to the growth of currency being in direct correlation with the growth of import and in the inverse relationship with the parameters of self-sustainment. The latter means that in regards to that market it is required to carry out a specific industrial policy.

The hypothesis about the absence of relationship between exchange rate and import in this case is explained by correlation and determination coefficients, which are insignificant.

In cases when a significant part of goods is produced for export and the internal market is fully secured by domestic providers the inverse relationship between exchange rates, selfsustainment and import share can be observed. This is most likely due to the fact that in case of growth in foreign exchange rates the volume of export increases (that on its part decreases the share of production incurred by consumption). Thus, Fertilizer mineral and Timber circular are examples of that. 
Relationship between parameters may differ in cases when the state program of substitution is realized in regards to the product and depends on the current market situation.

If the state program of import substitution is carried out in relation to the product, depending on the situation on the market, the nature of the relationship of indicators may be different. For example, in the market of medicines self-sufficiency is quite low, and the share of imports in consumption is much higher than 1 . This means that in this market there is an extremely negative situation: imports are many times higher than production and the trend to increase the share of imports in consumption remains. Moreover, medicines are socially important goods. The connection of self-sufficiency with the exchange rate in this case should not be any noticeable-there is no alternative to imports.

The assumption that there is no effect of the exchange rate on self-sufficiency is confirmed by the values of the correlation and determination coefficients, which are insignificant.

The situation in the car market (a state-supported industry) is different. It can be noted that the impact of the dollar on self-sufficiency and the share of imports in consumption is extremely high, despite of the huge funds spent on the program of state support for domestic producers and the placement of foreign enterprises in the country. When imported cars became less affordable, demand switched to nationally assembled cars. The data show that the share of imports in automobile consumption is more influenced by the exchange rate than by industrial policy measures.

It should be noted that the above examples concerned those examples when import substitution is in line with industrial policy. However, often the decision on import substitution is made for political (and other) reasons. In this case, import substitution programs show not so impressive results. This is primarily due to the lack of a base (for example, the production of motors for ships or microcircuits) or the lack of necessary legislation (which, for example, led to the "dominance" of dairy products with vegetable fats (palm oil) on the shelves of Russian stores). In these cases, import substitution is likely to become a negative factor, not only not improving, but negatively affecting economic growth indicators.

\section{Discussion}

The analysis showed that at the moment the process of import substitution in Russia is inconsistent. In those sectors where the implementation of import substitution took place from the standpoint of a proactive industrial policy, excellent results have been achieved. In other cases, the situation is not so good, and the results are more the result of external factors than economic policy. This predetermined the lack of long-term effect [16, 21]. In General, the process of import substitution in Russia was very difficult. he implementation of sanctions showed that the Russian industry is not ready for full self-sufficiency, that provoked the crisis from which the Russian economy emerged only in 2016.

Significant success occurs when import substitution is accompanied by innovative development. The right public policy can lead to a kind of "innovation leap", which is necessary for achievement of economic growth [22]. Such a situation arose, for example, in the military-technical sphere, when new technologies and state investments in their development led to a qualitative leap and allowed Russia to enter the 2nd place in the global arms trade market [23].

If we present import substitution as a long-term strategy of economic development of the state, accompanied by the strengthening of sanctions wars, we can assume that it will not only deplete the country's potential and slow down the pace of its development, but also have a negative impact on the welfare of all countries participating in the conflict. This 
strategy does not correspond to the current stage of development of the world economy, which has entered the path of globalization and intensive multilateral cooperation [24, 11].

One of the problems faced by import substitution at the present stage is that this instrument of industrial policy was introduced mainly as a political measure (the result of a political decision), and was not the result of a consistent economic policy: awareness of this problem came 10-15 years ago, but at the same time no significant comprehensive measures have been taken since then $[3,25]$.

Finally, the extended use of protectionist measures has a negative impact on global competitiveness, both at the enterprise and industry levels. Therefore, the long-term use of the practice of import substitution can ruin the national industry. The experience of import substitution in developing countries at the turn of 60-70s of XX century shows that the production of imported analogues inevitably caused an increase in imports of technologies, equipment and raw materials necessary for the organization of national production [11].

\section{Conclusion}

Import substitution is implemented in our country within the framework of the antisanctions program and is rather a tactical measure, which leads to a political rather than an economic result [26]. At the same time, import substitution as an instrument of economic policy and the achievement of economic security goals in the era of globalization can be considered as the basis of the strategy of structural adjustment of the national economy. In this case, thanks to the policy of sanctions (primarily by the United States and the European Union), the Russian economy has a unique chance to change the resource orientation and develop its own production [27]. However, in general, the import substitution program should be implemented regardless of political priorities and sanctions [28]. It is impossible to solve strategic problems by simple prohibitive measures [29], so the policy of import substitution should be based on a consistent system of measures, which requires an analysis of different types of economic policy that would take into account the requirements of economic security and the current situation in the Russian economy [30].

The research was supported by the grant of the Russian Foundation for Basic Research (RFBR) №19011-31177 OPN "Formation of a political strategy for the breakthrough development of the regional innovation system in the context of effective solutions to the problem of import substitution». The study was supported by the grant of the Russian Foundation for Basic Research (RFBR) №19-01131177 OPN "Formation of a political strategy for the breakthrough development of the regional innovation system in the context of effective solutions to the problem of import substitution".

\section{References}

1. L.N. Peregorodieva Advantages and disadvantages of the Russian economy for the import substitution strategy implementation. Bulletin of the Saratov State SocioEconomic University, 1, 70-72 (2011)

2. M. Gubina. Import Substitution and/or Export Orientation: the Case of Indian Pharmaceutical Industry. St Petersburg University Journal of Economic Studies, 35, 197222 (2019)

3. I. A. Blagikh. The crisis mechanism in the Russian economy and the government's anticrisis actions. Problems of the modern economy, 3, 31-35 (2015)

4. T. Scitovsky. Prospects for Latin American industrialization within the framework of economic integration: bases for analysis. The Process of Industrialization in Latin America, 34-48 (1969) 
5. W. Bauer. Import Substitution and Industrialization in Latin America: Experiences and Interpretations. Latin American Research Review, 7, 95-122 (1972)

6. A. Hart. Democracy and the successful use of economic sanctions. Political Research Quarterly, 53, 267-284 (2000)

7. R. R. Gumerov Once again, the questionable criteria and targets for national food security in the relevant doctrinal document. Russian economic journal, 2, 35-48 (2011)

8. V. V. Tulcheev et al. Competitiveness and import substitution of potatoes and products of its processing in the Russian Federation. Achievements of science and technology of agribusiness, 2, 58-60 (2013)

9. O. P. Chekmarev. Import substitution of agricultural products: potential, condition and prospects. Journal of New World Economics, 3, 39-55 (2016)

10. V. K. Senchagov (Ed.) Economic security of Russia (BINOM, Laboratorija znanij, Moscow, 2015)

11. A. N. Liakin, M. I. Rogov. Sanctions and counter-sanctions: using political instruments for the implementation of economic goals. National interests: priorities and security, 13, 1396-1414 (2017)

12. M. Klinova, E.Sidorova. Economic sanctions and their impact on Russian economic relations with the European Union. Problems of Economic Transition, 58, 218-234 (2016)

13. G.Shin, S.Choi and S. Luo. Do economic sanctions impair target economies? International Political Science Review, 37, 485-499 (2016)

14. A. N. Lyakin. Three crises in the Russian economy and one chain of events. St Petersburg University Journal of Economic Studies, 34, 4-25 (2018)

15. A. V. Uliukaev Meeting of the State Council September 18, 2014.Available at: http://news.kremlin.ru/news/46636 (2014)

16. A. A. Kirillovskaya, et al. The Newest economic policy, government regulation of the economy and economic security. Globalization and its Socio-Economic Consequences. 16th International Scientific Conference Proceedings. Zilina, Rajecke Teplice, Slovak Republic, 870-875 (2016)

17. V. N. Polovinkin, A. B. Fomichev. Fundamentals and prospects of the policy of import substitution in the domestic economy. Expert Union Journal, 12, 25-28 (2015)

18. V. V. Putin, The President's address to the Federal Assembly on December 4, 2014. Available at: http://www.kremlin.ru/news/47173\#sel=

19. Yu. V. Ermakov, A. A. Kirillovskaya. Development of innovative potential: State support and pseudo-innovations. Marketing MBA. Marketing management firms, 4, 127141 (2013).

20. E. Liu. Industrial policies in production networks. The Quarterly Journal of Economics, 134, 1883-1948 (2019)

21. I. Korhonen, A. N. Lyakin, Problems and prospects of Russia's economic growth. St Petersburg University Journal of Economic Studies, 33, 36-50 (2017)

22. P. Segerstrom. Innovation, imitation, and economic growth. Journal of Political Economy, 99, 807-827 (1991)

23. Zh. A. Aliaskarova. Import Substitution in Terms of Sanctions and Counter-Sanctions: Successes, Problems and Prospects. Marketing MBA. Marketing management firms, 9, 5-17 (2018) 
24. S. Mityakov, H. Tang, K. K. Tsui. International Politics and Import Diversification. The Journal of Law and Economics, 56, 1091-1121 (2013)

25. I. D. Ivanov. Domestic import substitution anatomy. Journal of International Economics, 4, 5-13 (2011)

26. S.K. Singh, D. Tripati Rao, Is monetary policy symmetrical in its effect on sectoral output?, Economics, Management, and Financial Markets 13, 11-31 (2018)

27. K. Falkowski, Trade interdependence between Russia vs. the European Union and China within the context of the competitiveness of the Russian economy, Equilibrium. Quarterly Journal of Economics and Economic Policy 13, 667-687 (2018)

28. B. Chapman, Sloan on geopolitics, geography and strategic history in geopolitics, Geopolitics, History, and International Relations 10, 7-16 (2018)

29. H. Hanappi, Metamorphosis in political economy: A new combination of three disparate ideas, Journal of Self-Governance and Management Economics 6, 92-112 (2018)

30. V. Spitsin, A. Mikhalchuk, I. Pavlova, L. Spitsina, Labor indicators and manufacturing companies ownership patterns in Russia and its regions: Results of quantitative analysis, Oeconomia Copernicana 9, 261-285 (2018) 